\title{
Carbon tetrachloride induced kidney and lung tissue damages and antioxidant activities of the aqueous rhizome extract of Podophyllum hexandrum
}

Showkat Ahmad Ganie ${ }^{1}$, Ehtishamul Haq ${ }^{3}$, Abid Hamid ${ }^{4}$, Yasrib Qurishi', Zahid Mahmood ${ }^{1}$, Bilal Ahmad Zargar², Akbar Masood ${ }^{1}$, Mohmmad Afzal Zargar ${ }^{1 *}$

\begin{abstract}
Background: The present study was conducted to evaluate the in vitro and in vivo antioxidant properties of aqueous extract of Podophyllum hexandrum. The antioxidant potential of the plant extract under in vitro situations was evaluated by using two separate methods, inhibition of superoxide radical and hydrogen peroxide radical. Carbon tetrachloride $\left(\mathrm{CCl}_{4}\right)$ is a well known toxicant and exposure to this chemical is known to induce oxidative stress and causes tissue damage by the formation of free radicals.

Methods: 36 albino rats were divided into six groups of 6 animals each, all animals were allowed food and water ad libitum. Group I (control) was given olive oil, while the rest groups were injected intraperitoneally with a single dose of $\mathrm{CCl}_{4}(1 \mathrm{ml} / \mathrm{kg})$ as a $50 \%(\mathrm{~V} / \mathrm{v})$ solution in olive oil. Group II received $\mathrm{CCl}_{4}$ only. Group III animals received vitamin $\mathrm{E}$ at a concentration of $50 \mathrm{mg} / \mathrm{kg}$ body weight and animals of groups $\mathrm{IV}, \mathrm{V}$ and $\mathrm{VI}$ were given extract of Podophyllum hexandrum at concentration dose of 20,30 and $50 \mathrm{mg} / \mathrm{kg}$ body weight. Antioxidant status in both kidney and lung tissues were estimated by determining the activities of antioxidative enzymes, glutathione reductase (GR), glutathione peroxidase (GPX), glutathione-S-transferase (GST) and superoxide dismutase (SOD); as well as by determining the levels of reduced glutathione (GSH) and thiobarbituric acid reactive substances (TBARS). In addition, superoxide and hydrogen peroxide radical scavenging activity of the extract was also determined.
\end{abstract}

Results: Results showed that the extract possessed strong superoxide and hydrogen peroxide radical scavenging activity comparable to that of known antioxidant butylated hydroxy toluene (BHT). Our results also showed that $\mathrm{CCl}_{4}$ caused a marked increase in TBARS levels whereas GSH, SOD, GR, GPX and GST levels were decreased in kidney and lung tissue homogenates of $\mathrm{CCl}_{4}$ treated rats. Aqueous extract of Podophyllum hexandrum successfully prevented the alterations of these effects in the experimental animals.

Conclusion: Our study demonstrated that the aqueous extract of Podophyllum hexandrum could protect the kidney and lung tissue against $\mathrm{CCl}_{4}$ induced oxidative stress probably by increasing antioxidant defense activities.

\section{Background}

Reactive oxygen species, including superoxide radicals $\left(\mathrm{O}_{2}{ }^{-}-\right)$, hydrogen peroxide $\left(\mathrm{H}_{2} \mathrm{O}_{2}\right)$ and hydroxyl radicals $\left(\mathrm{OH}^{*}\right)$ are generated as byproducts of normal metabolism [1,2]. Cumulative oxidative damage leads to numerous diseases and disorders [3]. The enhanced

\footnotetext{
* Correspondence: zargarma@kashmiruniversity.ac.in

'Department of Biochemistry, University of Kashmir, Srinagar, 190006, India Full list of author information is available at the end of the article
}

production of free radicals and oxidative stress can also be induced by a variety of factors such as radiation or exposure to heavy metals and xenobiotics (e.g., carbon tetrachloride) [4]. Carbon tetrachloride $\left(\mathrm{CCl}_{4}\right)$ intoxication in animals is an experimental model that mimics oxidative stress in many pathophysiological situations [5]. $\mathrm{CCl}_{4}$ intoxication in various studies has demonstrated that $\mathrm{CCl}_{4}$ causes free radical generation in many tissues such as liver, kidney, heart, lung, brain

\section{Biomed Central}

(c) 2011 Ganie et al; licensee BioMed Central Ltd. This is an Open Access article distributed under the terms of the Creative Commons Attribution License (http://creativecommons.org/licenses/by/2.0), which permits unrestricted use, distribution, and reproduction in any medium, provided the original work is properly cited. 
and blood [6]. The toxicity of $\mathrm{CCl}_{4}$ probably depends on formation of the trichloromethyl radical $\left(\mathrm{CCl}_{3}{ }^{\circ}\right)$, which in the presence of oxygen interacts with it to form the more toxic trichloromethyl peroxyl radical $\left(\mathrm{CCl}_{3} \mathrm{O}_{2}{ }^{\circ}\right)$ [7]. Studies also showed that various herbal extracts could protect organs against $\mathrm{CCl}_{4}$ induced oxidative stress by altering the levels of increased lipid peroxidation and enhancing the decreased activities of antioxidant enzymes, like superoxide dismutase (SOD), catalase (CAT) and glutathione-S-transferase (GST) as well as enhanced the decreased level of the reduced glutathione (GSH) [8]. In the modern medicine, plants occupy a significant berth as raw materials for some important drug preparations [9]. Podophyllum hexandrum (PH) has been extensively exploited in traditional Ayurvedic system of medicine for treatment of a number of ailments like Condyloma acuminata, Taenia capitis, monocytoid leukemia, Hodgkins disease, nonHodgkin's Lymphoma, cancer of brain, lung, bladder and venereal warts [10]. PH is reported to contain a number of compounds with significant pharmacological properties, e.g. epipodophyllotoxin, podophyllotoxone, 4-methylpodophyllotoxin, aryltetrahydronaphthalene lignans, flavonoids such as quercetin, quercetin-3-glycoside, 4-demethylpodophyllotoxin glycoside, podophyllotoxinglycoside, kaempferol and kaempferol-3-glucoside $[11,12]$. In this particular study, protective role of aqueous extract of the Podophyllum hexandrum was evaluated against free radical mediated damages under in vitro and in vivo situations. In vitro assays were carried on superoxide radical scavenging activity and hydrogen peroxide radical scavenging activity. Here, kidney and lung toxicity was induced by administering a single dose of $\mathrm{CCl}_{4}$ into experimental adult male albino rats and radical scavenging activity of the extract was evaluated by measuring the levels of GSH and extent of lipid peroxidation in kidney and lung tissue homogenates and activity of antioxidant enzymes via SOD, GP, GR and GST. In addition, study on the effect of a known antioxidant, vitamin $\mathrm{E}$, was also included against $\mathrm{CCl}_{4}$ induced kidney and lung oxidative stress. The major aim of the present study was to examine the protective mechanisms of aqueous extract of $\mathrm{PH}$ in kidney and lung tissues in carbon tetrachloride intoxicated rats.

\section{Methods}

\section{Plant material collection and extraction}

The rhizome of Podophyllum hexandrum was collected from higher reaches of Aharbal, Shopian, J\&K, India in the month of May and June, identified by the Centre of Plant Taxonomy, Department of Botany, University of Kashmir, and authenticated by Dr. Irshad Ahmad Nawchoo (Department of Botany) and Akhter Hussain Malik
(Curator, Centre for Plant Taxonomy, University of Kashmir). A reference specimen has been retained in the herbarium of the Department of Botany at the University of Kashmir under reference number KASH- bot/ Ku/PH- 702- SAG.

The plant material (rhizome) was dried in the shade at $30 \pm 2^{\circ} \mathrm{C}$. The dried rhizome material was ground into a powder using mortar and pestle and passed through a sieve of $0.3 \mathrm{~mm}$ mesh size. The powder obtained was extracted with water using a Soxhlet extractor $\left(60-80^{\circ}\right.$ C). The extract was then concentrated with the help of rotary evaporator under reduced pressure and the solid extract was stored in refrigerator for future use.

\section{Animals}

Adult male albino rats of Wistar strain weighing 200-250 g used throughout this study were purchased from the Indian Institute of Integrative Medicine Jammu (IIIM). The animals had access to food and water ad libitum. The animals were maintained in a controlled environment under standard conditions of temperature and humidity with an alternating $12 \mathrm{hr}$ light and dark cycle. The animals were maintained in accordance with the guidelines prescribed by the National Institute of Nutrition, Indian Council of Medical Research and the study was approved by the Animal Ethics Committee of the University of Kashmir.

\section{Experimental methods}

\section{Assessment of superoxide anion radical scavenging} property

Superoxide anion radical generated by the Xanthine/ Xanthine oxidase system was spectrophotometrically determined by monitoring the product of nitroblue tetrazolium (NBT) using the method of Jung [13]. A reaction mixture containing $1.0 \mathrm{ml}$ of $0.05 \mathrm{M}$ phosphate buffer (pH 7.4), $0.04 \mathrm{ml}$ of $0.15 \%$ BSA, $0.04 \mathrm{ml}$ of $15.0 \mathrm{mM} \mathrm{NBT}$ and various concentrations of plant extract and known antioxidant was incubated at $25^{\circ} \mathrm{C}$ for $10 \mathrm{~min}$, and the reaction was then started by adding $0.04 \mathrm{ml}$ of $1.5 \mathrm{U} / \mathrm{ml}$ Xanthine oxidase and again incubated at $25^{\circ} \mathrm{C}$ for $20 \mathrm{~min}$. The absorbance of the reaction mixture was measured at $560 \mathrm{~nm}$. Decreased absorbance of the reaction mixture indicates increased superoxide anion radical scavenging activity.

The scavenging activity of the plant extract on Superoxide anion radical was expressed as:

$$
\% \text { inhibition }=\left[\left(\mathrm{A}_{0}-\mathrm{A}_{1}\right) / \mathrm{A}_{0}\right] \times 100
$$

Where $\mathrm{A}_{0}$ was the absorbance of the control and $\mathrm{A}_{1}$ was absorbance in the presence of Podophyllum hexandrum extract/known antioxidant. 


\section{Assessment of Hydrogen peroxide scavenging activity}

The ability of Podophyllum hexandrum aqueous extract to scavenge hydrogen peroxide was evaluated according to the method of Ruch [14]. A solution of $\mathrm{H}_{2} \mathrm{O}_{2}(2$ $\mathrm{mmol}$ ) was prepared in phosphate buffer $(\mathrm{pH} 7.5)$. Plant extract $(50-300 \mu \mathrm{g} / \mathrm{ml})$ was added to the hydrogen peroxide solution $(0.6 \mathrm{ml})$. Absorbance of hydrogen peroxide at $230 \mathrm{~nm}$ was determined after 15 minutes against a blank solution containing phosphate buffer without hydrogen peroxide. BHT was taken as known standard. The scavenging activity of the plant extract on $\mathrm{H}_{2} \mathrm{O}_{2}$ was expressed as:

$\%$ scavenged $\left[\mathrm{H}_{2} \mathrm{O}_{2}\right]=\left[\left(\mathrm{A}_{0}-\mathrm{A}_{1}\right) / \mathrm{A}_{0}\right] \times 100$

Where $A_{0}$ is the absorbance of the control and $A_{1}$ is absorbance in the presence of plant extract and known standard.

\section{Dosage and treatment}

Rats were divided into six groups each containing six rats. The plant extract was employed at oral doses of 20 , 30 and $50 \mathrm{mg} / \mathrm{kg}$-day. The extract was suspended in normal saline such that the final volume of extract at each dose was $1 \mathrm{ml}$ which was fed to rats by gavage.

Group I - Received olive oil vehicle only at $5 \mathrm{ml} / \mathrm{kg}$-day.

Group II - Received $\mathrm{CCl}_{4}$ in olive oil vehicle only.

Group III - Were administered with vitamin E (50 mg/kg-day).

Group IV - Received 20 mg/kg-day extract orally for fifteen days.

Group V - Received $30 \mathrm{mg} / \mathrm{kg}$-day extract orally for fifteen days.

Group VI - Received $50 \mathrm{mg} / \mathrm{kg}$-day orally for fifteen days.

On the thirteenth day, animals from groups II-VI were injected intraperitoneally with $\mathrm{CCl}_{4}$ in olive oil vehicle at a dosage of $1 \mathrm{ml} / \mathrm{kg}$ bw. The rats were sacrificed $48 \mathrm{hr}$ after $\mathrm{CCl}_{4}$ administration and kidney and lung tissue was isolated out, and post mitochondrial supernatant of both the tissues was prepared.

Preparation of post mitochondrial supernatant (PMS)

Kidney and lung tissue was washed in ice-cold $1.15 \% \mathrm{KCl}$ and homogenized in a homogenizing buffer $(50 \mathrm{mM}$ Tris$\mathrm{HCl}, 1.15 \% \mathrm{KCl} \mathrm{pH} \mathrm{7.4)} \mathrm{using} \mathrm{a} \mathrm{Teflon} \mathrm{homogenizer.} \mathrm{The}$ homogenate was centrifuged at 9,000 g for 20 minutes to remove debris. The supernatant was further centrifuged at $15,000 \mathrm{~g}$ for 20 minutes at $4^{\circ} \mathrm{C}$ to get PMS which was used for various biochemical assays. Protein concentration was estimated by the method of Lowry [15].

\section{Estimation of lipid peroxidation (PMS)}

Lipid peroxidation in tissues was estimated by the formation of thiobarbituric acid reactive substances
(TBARS) by the method of Nichans and Samuelson [16]. In brief $0.1 \mathrm{ml}$ of tissue homogenate (PMS; Tris$\mathrm{HCl}$ buffer, $\mathrm{pH} 7.5)$ was treated with $2 \mathrm{ml}$ of $(1: 1: 1$ ratio) TBA-TCA- $\mathrm{HCl}$ reagent $(0.37 \%$ thiobarbituric acid, $0.25 \mathrm{~N} \mathrm{HCl}$, and 15\% TCA), placed in boiling water bath for $15 \mathrm{~min}$, cooled and centrifuged at room temperature for $10 \mathrm{~min}$. The absorbance of the clear supernatant was measured against reference blank at $535 \mathrm{~nm}$.

\section{Determination of total sulphydryl groups}

The acid soluble sulphydryl groups (non protein thiols of which more than $93 \%$ is reduced glutathione (GSH) forms a yellow colored complex with DTNB that shows the absorption maximum at $412 \mathrm{~nm}$. The assay procedure will be followed to that of Moren [17]. $500 \mu \mathrm{l}$ of homogenate precipitated with $100 \mu \mathrm{l}$ of $25 \% \mathrm{TCA}$, will be then subjected to centrifugation at $3000 \mathrm{~g}$ for $10 \mathrm{~min}$ utes to settle the precipitate. $100 \mu \mathrm{l}$ of the supernatant obtained shall be added to the test tube containing the $2 \mathrm{ml}$ of $0.6 \mathrm{mM}$ DTNB and $0.9 \mathrm{ml}$ of $0.2 \mathrm{mM}$ sodium phosphate buffer ( $\mathrm{pH}$ 7.4). The yellow color obtained will be measured at $412 \mathrm{~nm}$ against the reagent blank which contains $100 \mu \mathrm{l}$ of $25 \%$ TCA in place of the supernatant. Sulphydryl content shall be calculated using the DTNB molar extension coefficient of 13,100.

\section{Glutathione peroxidase $\left(G P_{X}\right)$}

$\mathrm{GP}_{\mathrm{X}}$ activity was assayed using the method of Sharma [18]. The assay mixture consists of $1.49 \mathrm{ml}$ of sodium phosphate buffer (0.1 M pH 7.4), $0.1 \mathrm{ml}$ EDTA (1 mM), $0.1 \mathrm{ml}$ sodium azide $(1 \mathrm{mM}), 0.1 \mathrm{ml} 1 \mathrm{mM} \mathrm{GSH}, 0.1 \mathrm{ml}$ of NADPH $(0.02 \mathrm{mM}), 0.01 \mathrm{ml}$ of $1 \mathrm{mM} \mathrm{H}_{2} \mathrm{O}_{2}$ and $0.1 \mathrm{ml}$ PMS in a total volume of $2 \mathrm{ml}$. Oxidation of $\mathrm{NADPH}$ was recorded spectrophotometrically at $340 \mathrm{~nm}$ and the enzyme activity was calculated as nmoles $\mathrm{NADPH}$ oxidized $/ \mathrm{min} / \mathrm{mg}$ of protein, using $€$ of $6.22 \times$ $10^{3} \mathrm{M}^{-1} \mathrm{~cm}^{-1}$.

\section{Glutathione Reductase activity (GR)}

GR activity was assayed by the method of Sharma [18]. The assay mixture consisted of $1.6 \mathrm{ml}$ of sodium phosphate buffer (0.1 M pH 7.4), $0.1 \mathrm{ml}$ EDTA (1 mM), $0.1 \mathrm{ml} 1 \mathrm{mM}$ oxidized glutathione, $0.1 \mathrm{ml}$ of NADPH (0.02 mM), $0.01 \mathrm{ml}$ of $1 \mathrm{mM} \mathrm{H} \mathrm{H}_{2} \mathrm{O}_{2}$ and $0.1 \mathrm{ml}$ PMS in a total volume of $2 \mathrm{ml}$. The enzyme activity measured at $340 \mathrm{~nm}$ was calculated as nmoles of NADPH oxidized/ $\mathrm{min} / \mathrm{mg}$ of protein using $€$ of $6.22 \times 10^{3} \mathrm{M}^{-1} \mathrm{~cm}^{-1}$.

\section{Glutathione-S-transferase (GST) activity}

GST activity was assayed using the method of Haque [19]. The reaction mixture consisted of $1.67 \mathrm{ml}$ sodium phosphate buffer (0.1 M pH 6.5), $0.2 \mathrm{ml}$ of $1 \mathrm{mM} \mathrm{GSH}$, $0.025 \mathrm{ml}$ of $1 \mathrm{mM} \mathrm{CDNB}$ and $0.1 \mathrm{ml}$ of PMS in a total volume of $2 \mathrm{ml}$. The change in absorbance was recorded at $340 \mathrm{~nm}$ and the enzyme activity was calculated as nmoles of CDNB conjugates formed $/ \mathrm{min} / \mathrm{mg}$ protein using $€$ of $9.6 \times 10^{3} \mathrm{M}^{-1} \mathrm{~cm}^{-1}$. 
Super oxide dismutase activity (SOD)

SOD activity was estimated by Beauchamp and Fridovich [20]. The reaction mixture consisted of $0.5 \mathrm{ml}$ of hepatic PMS, $1 \mathrm{ml}$ of $50 \mathrm{mM}$ sodium carbonate, $0.4 \mathrm{ml}$ of $25 \mu \mathrm{M}$ NBT and $0.2 \mathrm{ml}$ of $0.1 \mathrm{mM}$ EDTA. The reaction was initiated by addition of $0.4 \mathrm{ml}$ of $1 \mathrm{mM}$ hydroxylamine-hydrochloride. The change in absorbance was recorded at $560 \mathrm{~nm}$. The control was simultaneously run without tissue homogenate. Units of SOD activity were expressed as the amount of enzyme required to inhibit the reduction of NBT by $50 \%$.

\section{Statistical analysis}

The values are expressed as mean \pm standard deviation (SD). The results were evaluated by using the SPSS (version 12.0) and Origin 6 softwares and evaluated by oneway ANOVA followed by Bonferroni t-test. Statistical significance was considered when value of $P$ was $<0.5$.

\section{Results}

\section{Superoxide anion radical scavenging activity}

Superoxide anion radical scavenging activity of varying amount of aqueous extract of Podophyllum hexandrum was determined by Xanthine-Xanthine oxidase system. Table 1 shows the percentage inhibition of superoxide radical generation of 50-300 $\mu \mathrm{g}$ of extract and comparison with the same amount of BHT. The aqueous extract of Podophyllum hexandrum exhibited somewhat lesser superoxide radical scavenging activity than BHT. The percentage inhibition of superoxide generation at a concentration of $300 \mu \mathrm{g} / \mathrm{ml}$ of aqueous extract of Podophyllum hexandrum and BHT was however found as 81.64 and $85.71 \%$, suggesting that Podophyllum hexandrum has strong superoxide radical scavenging activity at higher concentration.

\section{Hydrogen peroxide radical scavenging activity}

Table 2 shows the scavenging effect of Podophyllum hexandrum extract on $\mathrm{H}_{2} \mathrm{O}_{2}$ and the comparison with standard $\mathrm{BHT}$ in an amount dependent manner. As

Table 1 Effect of Podophyllum hexandrum aqueous extract and known antioxidant (BHT) on superoxide radical scavenging activity

\begin{tabular}{ccc}
\hline Concentration $(\boldsymbol{\mu g} / \mathbf{m l})$ & Aqueous extract of P.H & BHT \\
\hline $50(\mu \mathrm{g} / \mathrm{ml})$ & $17.01 \pm 2.08$ & $40.30 \pm 3.78$ \\
\hline $100(\mu \mathrm{g} / \mathrm{ml})$ & $33.62 \pm 0.75$ & $52.16 \pm 2.55$ \\
\hline $150(\mu \mathrm{g} / \mathrm{ml})$ & $47.19 \pm 2.55$ & $63.65 \pm 2.31$ \\
\hline $200(\mu \mathrm{g} / \mathrm{ml})$ & $61.44 \pm 2.85$ & $71.63 \pm 2.2$ \\
\hline $250(\mu \mathrm{g} / \mathrm{ml})$ & $72.74 \pm 3.64$ & $81.64 \pm 1.11$ \\
\hline $300(\mu \mathrm{g} / \mathrm{ml})$ & $81.64 \pm 1.11$ & $85.71 \pm 1.40$ \\
\hline
\end{tabular}

Effect of Podophyllum hexandrum aqueous extract and known antioxidant (BHT) on superoxide radical scavenging activity. Absorbance of control at $560 \mathrm{~nm}=0.899 \pm 0.25$. The results represent mean \pm S.D of 3 separate experiments.
Table 2 Effect of Podophyllum hexandrum aqueous extract and known antioxidant (BHT) on hydrogen peroxide radical scavenging activity

\begin{tabular}{ccc}
\hline Concentration $(\boldsymbol{\mu g} / \mathrm{ml})$ & Aqueous extract of P.H & BHT \\
\hline $50(\mu \mathrm{g} / \mathrm{ml})$ & $22.30 \pm 1.20$ & $30.32 \pm 1.14$ \\
\hline $100(\mu \mathrm{g} / \mathrm{ml})$ & $32.07 \pm 4.27$ & $45.86 \pm 1.50$ \\
\hline $150(\mu \mathrm{g} / \mathrm{ml})$ & $43.10 \pm 1.15$ & $52.12 \pm 1.15$ \\
\hline $200(\mu \mathrm{g} / \mathrm{ml})$ & $53.45 \pm 1.57$ & $58.64 \pm 1.98$ \\
\hline $250(\mu \mathrm{g} / \mathrm{ml})$ & $62.22 \pm 2.75$ & $66.66 \pm 1.90$ \\
\hline $300(\mu \mathrm{g} / \mathrm{ml})$ & $67.51 \pm 2.02$ & $72.17 \pm 1.50$
\end{tabular}

Effect of Podophyllum hexandrum aqueous extract and known antioxidant (BHT) on hydrogen peroxide radical scavenging activity. Absorbance of control at $230 \mathrm{~nm}=0.665 \pm 0.15$. The results represent mean \pm S.D of 3 separate experiments.

shown in table the extract and BHT exhibited 67.51 and $72.17 \%$ scavenging activity on hydrogen peroxide at $300 \mu \mathrm{g} / \mathrm{ml}$ respectively, again suggests that Podophyllum hexandrum extract possess a strong free radical scavenging activity, comparable to that of BHT.

\section{Effect of aqueous extract on lipid peroxidation in $\mathrm{CCl}_{4}$ treated rats}

TBARS concentrations (expressed as MDA) in the kidney and lung tissue homogenates of all the experimental animals are shown in Figure 1 and 2. After $\mathrm{CCl}_{4}$

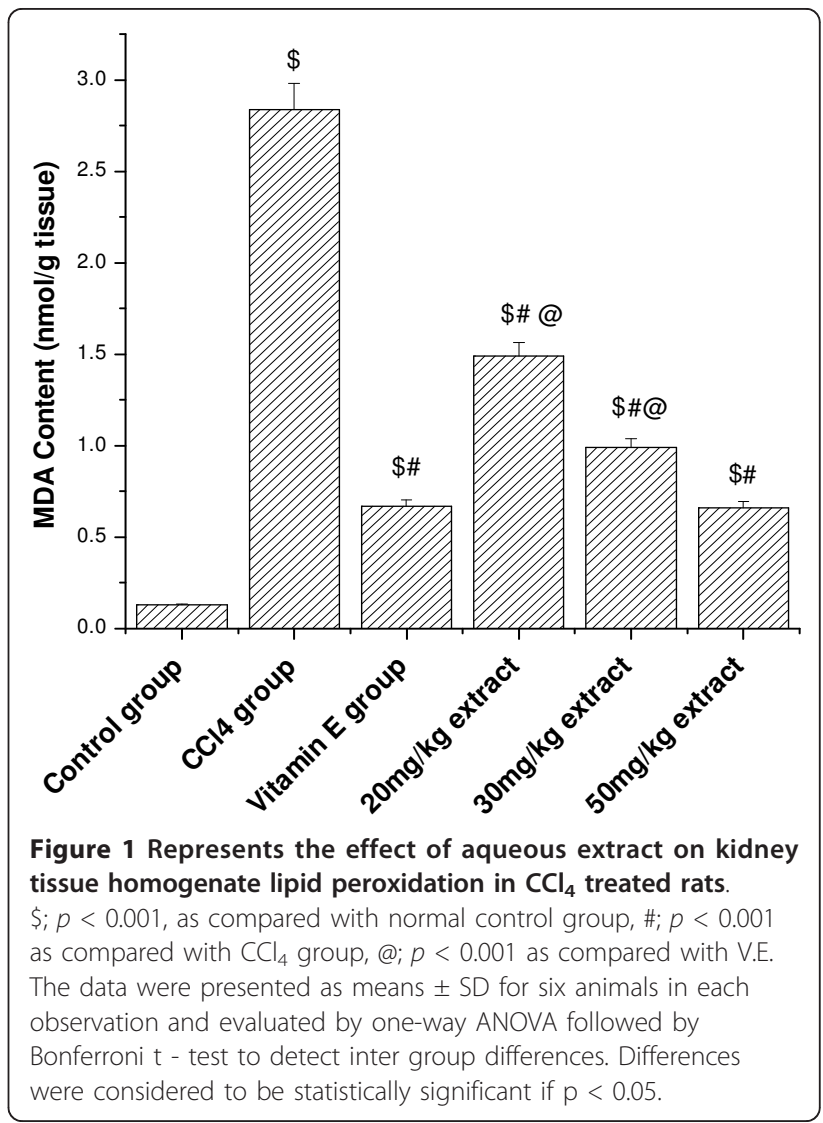




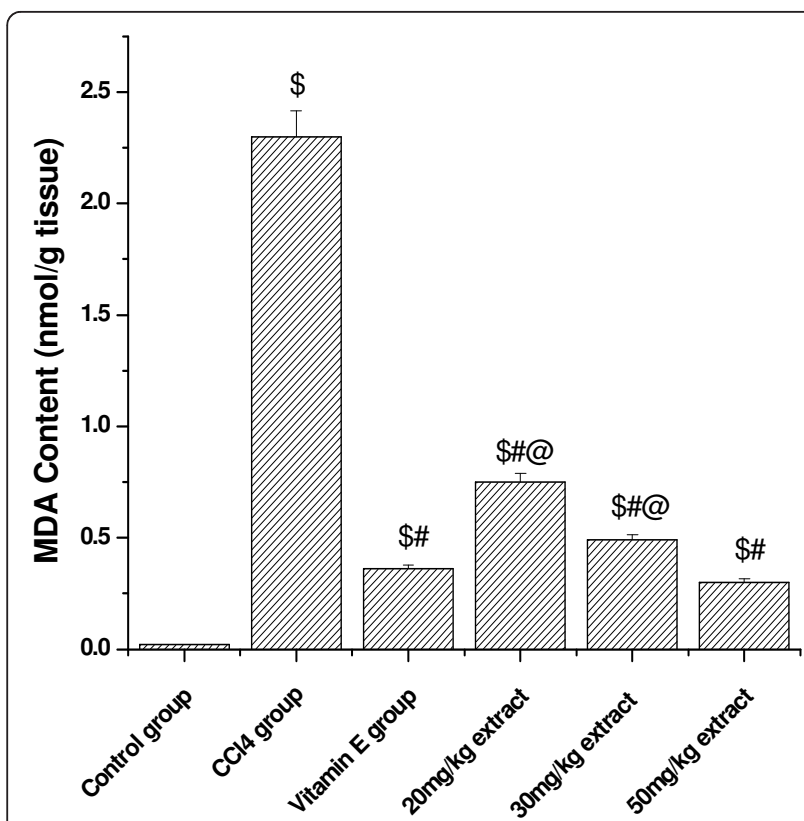

Figure 2 Represents the effect of aqueous extract on lung tissue homogenate lipid peroxidation in $\mathrm{CCl}_{4}$ treated rats. \$; $p<0.001$, as compared with normal control group, \#; $p<0.001$ as compared with $\mathrm{CCl}_{4}$ group, @; $p<0.001$ as compared with V.E. The data were presented as means \pm SD for six animals in each observation and evaluated by one-way ANOVA followed by Bonferroni $t$ - test to detect inter group differences. Differences were considered to be statistically significant if $p<0.05$.

administration, the MDA levels increased significantly from 0.12 to $2.8 \mathrm{nmol} / \mathrm{mg}$ protein in kidney tissue homogenate and in lung tissue homogenate, the MDA level increased from 0.02 to $2.30 \mathrm{nmol} / \mathrm{mg}$ protein. However pretreatment of aqueous extract of Podophyllum hexandrum for 15 days decreased the MDA level in a dose dependent manner in both tissue homogenates. Vitamin E treated animals also showed significant decrease in the MDA levels as compared to $\mathrm{CCl}_{4}$ treated animals.

In order to investigate whether the antioxidant activities of Podophyllum hexandrum are mediated by an increase in antioxidant enzymes, we measured GPx, GR, SOD and GST activities in kidney and lung tissues of rats treated with Podophyllum hexandrum rhizome aqueous extract. In the present study, treatment of rats with Podophyllum hexandrum rhizome aqueous extract significantly increased rat, kidney and lung tissue SOD, $\mathrm{GP}_{\mathrm{X}}, \mathrm{GR}$ and GST activities.

\section{Effect on (GP $\mathrm{X}$ activity)}

(Figure 3 and 4) shows that glutathione peroxidase activity in kidney and lung tissue was significantly decreased in $\mathrm{CCl}_{4}$ treated animals compared to control. Pretreatment with aqueous extract significantly

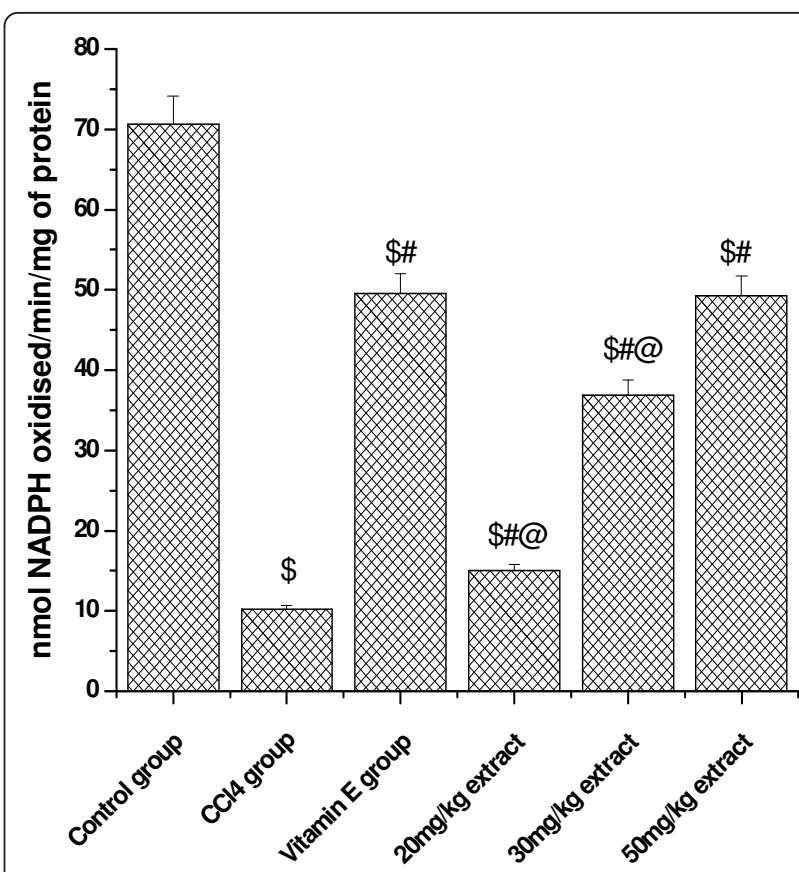

Figure 3 Represents the dose dependent effect of aqueous extract of Podophyllum hexandrum on glutathione peroxidase activity against $\mathrm{CCl} 4$ induced toxicity in Kidney tissue homogenate. $\$ ; p<0.001$, as compared with normal control group, $\# ; p<0.001$ as compared with $\mathrm{CCl}_{4}$ group, @; $p<0.001$ as compared with V.E. The data were presented as means \pm SD for six animals in each observation and evaluated by one-way ANOVA followed by Bonferroni $t$ - test to detect inter group differences. Differences were considered to be statistically significant if $p<0.05$.

increased the $\mathrm{GP}_{\mathrm{X}}$ activity in a dose dependent manner. At higher concentrations of plant extract $(50 \mathrm{mg} / \mathrm{kg}$ dose level), the activity was increased to 49.30 from $\mathrm{CCl}_{4}$ treated group (11.20) in kidney tissue and the level was increased to 11.93 from 3.51 at the same concentration in lung tissue. Vitamin E $(50 \mathrm{mg} / \mathrm{kg})$ treated animals also showed significant increase in $\mathrm{GP}_{\mathrm{X}}$ activity in both the tested organs.

\section{Effect on GR activity}

Glutathione reductase (GR) activity was significantly decreased in $\mathrm{CCl}_{4}$ treated animals when compared to control group. There was a significant increase in glutathione reductase activity observed in aqueous extract treated groups in both the tested organs. At the higher concentration of plant extract $(50 \mathrm{mg} / \mathrm{kg})$ the activity increased many fold (Figure 5 and 6). Similar results were obtained with vitamin $\mathrm{E}$.

\section{Effect on SOD activity}

Effects of $\mathrm{CCl}_{4}$ and $\mathrm{CCl}_{4}$ plus aqueous extract of Podophyllum hexandrum treatments on kidney and lung tissue SOD activity is presented in Figure 7. The SOD activity of both the tested organs significantly decreased 


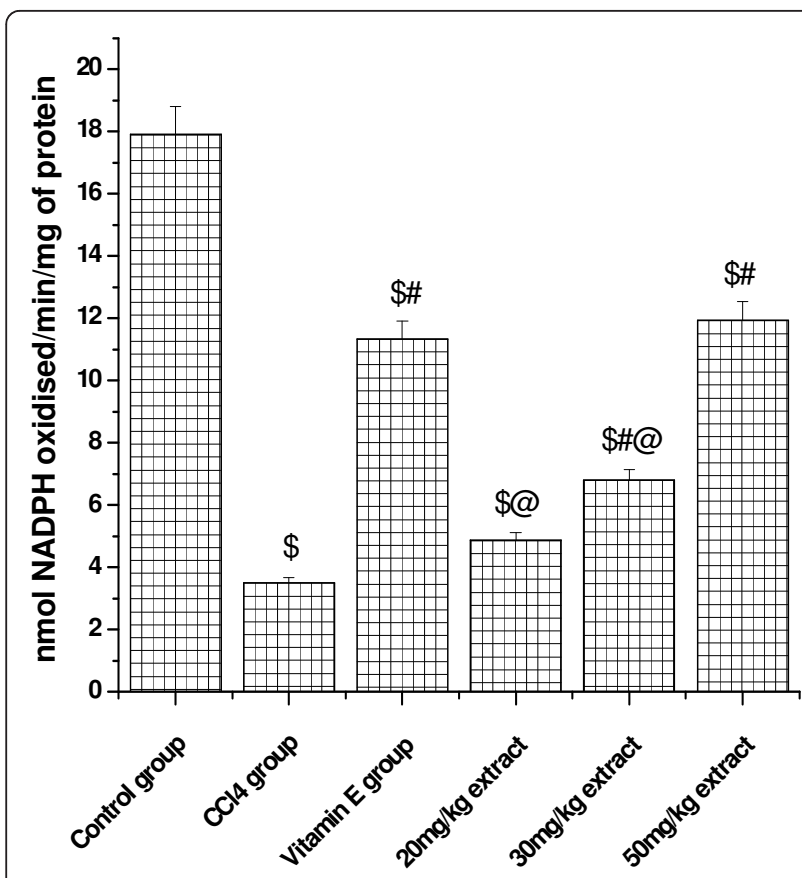

Figure 4 Represents the dose dependent effect of aqueous extract of Podophyllum hexandrum on glutathione peroxidase activity against $\mathrm{CCl} 4$ induced toxicity in lung tissue

homogenate. $\$ ; p<0.001$, as compared with normal control group, $\# ; p<0.001$ as compared with $\mathrm{CCl}_{4}$ group, @; $p<0.001$ as

compared with V.E. The data were presented as means \pm SD for six animals in each observation and evaluated by one-way ANOVA followed by Bonferroni $t$ - test to detect inter group differences. Differences were considered to be statistically significant if $p<0.05$.

in $\mathrm{CCl}_{4}$ treated group. Administration of extract proved significantly better in restoring the altered activity of antioxidant enzyme like SOD, and increased the activity in a dose dependent manner in both organs. Similar results were observed in vitamin E treated group.

\section{Effect on GSH level}

$\mathrm{CCl}_{4}$ administration markedly decreased the levels of reduced glutathione in both the kidney (control $=54.73$ microgram $/ \mathrm{mg}$ protein) and lung tissue (control $=31.93$ microgram/mg protein) to $9.62\left(\mathrm{CCl}_{4}\right.$ group kidney) and $6.53\left(\mathrm{CCl}_{4}\right.$ group lung) demonstrating oxidative stress. Pretreatment with the aqueous extract of Podophyllum hexandrum significantly ameliorated $\mathrm{CCl}_{4}$-induced depletion of GSH in both lung and kidney in a dose dependent manner (Figure 8 and 9).

\section{Effect on GST activity}

GST activity as measured from the lung and kidney tissue homogenates of all the experimental animals have been shown in Figure 10. In the kidney tissue homogenate decreased GST activity was observed in $\mathrm{CCl}_{4}$ treated animals (17.71 nmoles) compared to the normal

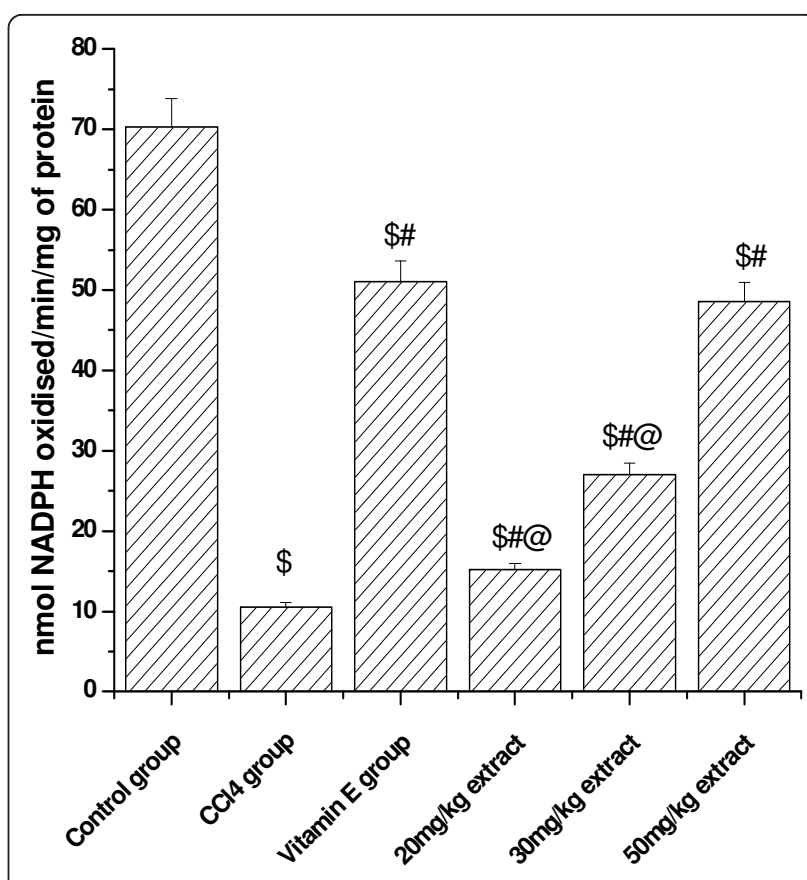

Figure 5 Represents the effect of aqueous extract of Podophyllum hexandrum on the glutathione reductase activity in kidney tissue. $\$ ; p<0.001$, as compared with normal control group, \#; $p<0.001$ as compared with $\mathrm{CCl}_{4}$ group, @; $p<0.001$ as compared with V.E. The data were presented as means \pm SD for six animals in each observation and evaluated by one-way ANOVA followed by Bonferroni $t$ - test to detect inter group differences. Differences were considered to be statistically significant if $p<0.05$.

control group (38.28 nmoles). Pretreatment with the aqueous extract for 15 days prior to $\mathrm{CCl}_{4}$ intoxication enhanced that activity significantly in a dose dependent manner. In the lung homogenate GST activity of $\mathrm{CCl}_{4}$ treated group (5.22 nmoles) was lower compared to that in the normal group (9.11 nmoles), while the GST activity was found to be increased in the lung tissue homogenate of rats treated with aqueous extract at the concentration of 20 and $30 \mathrm{mg} / \mathrm{kg}$ bw for 15 days prior to $\mathrm{CCl}_{4}$ treatment. GST activity in vitamin $\mathrm{E}$ and $50 \mathrm{mg} / \mathrm{kg}$ bw plant extract pretreated group was close to the normal level in lung tissue.

\section{Discussion}

$\mathrm{CCl}_{4}$ when administrated is distributed and deposited to organs such as the liver, brain, kidney, lung and heart [21]. The reactive metabolite trichloromethyl radical $\left({ }^{\circ} \mathrm{CCl} 3\right)$ and trichloromethyl peroxide radical $\left(\mathrm{CCl}_{3} \mathrm{O}_{2} \cdot\right)$ has been formed from the metabolic conversion of $\mathrm{CCl}_{4}$ by cytochrome P-450. As $\mathrm{O}_{2}$ tension rises, a greater fraction of ${ }^{\circ} \mathrm{CCl}_{3}$ present in the system reacts very rapidly with $\mathrm{O}_{2}$ and more reactive free radicals, like $\mathrm{CCl}_{3} \mathrm{OO}{ }^{*}$ is generated from ${ }^{\circ} \mathrm{CCl}_{3}$. These free radicals initiate the peroxidation of membrane poly unsaturated fatty acids (PUFA), cell necrosis, GSH 


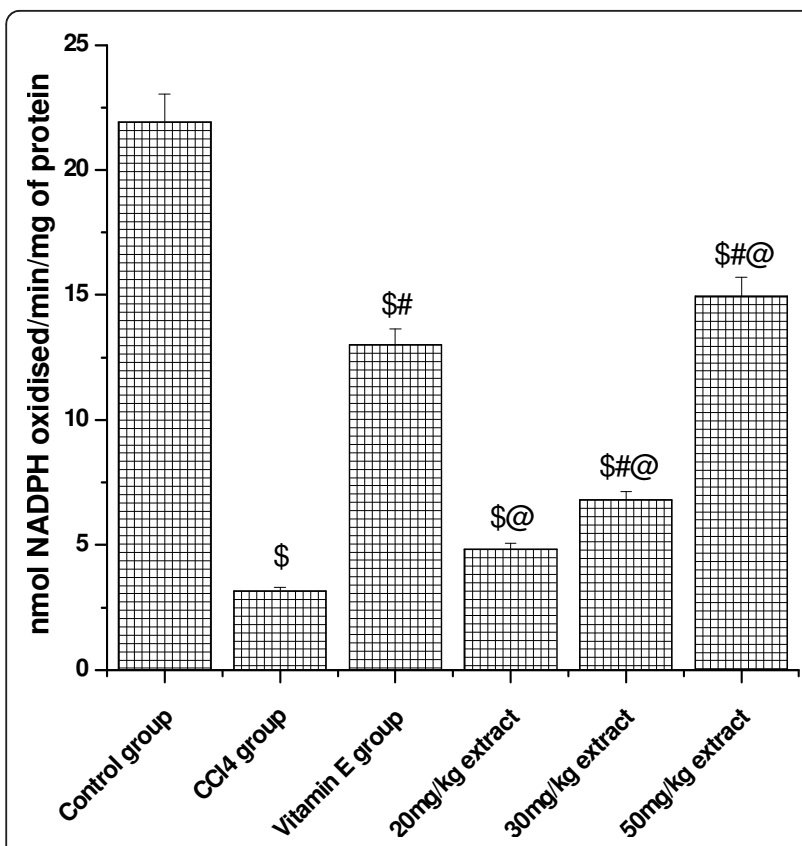

Figure 6 Represents the effect of aqueous extract of Podophyllum hexandrum on the glutathione reductase activity in lung tissue. $\$ ; p<0.001$, as compared with normal control group, \#; $p<0.001$ as compared with $\mathrm{CCl}_{4}$ group, @; $p<0.001$ as compared with V.E. The data were presented as means \pm SD for six animals in each observation and evaluated by one-way ANOVA followed by Bonferroni $t$ - test to detect inter group differences. Differences were considered to be statistically significant if $p<0.05$.

depletion, membrane damage and loss of antioxidant enzyme activity.

In this experimental study we investigated the protective effect of aqueous extract of Podophyllum hexandrum Free radicals e.g. superoxide radical, hydrogen peroxide and hydroxyl radical, from both endogenous and exogenous sources, are implicated in the etiology of several degenerative diseases, such as coronary artery disease, stroke, rheumatoid arthritis, diabetes and cancer [22]. High consumption of fruits and vegetables is associated with low risk for these diseases, which is attributed to the antioxidant vitamins and other phytochemicals $[23,24]$. The extent of initial damage caused by free radicals is further amplified by Fenton reaction generated hydroxyl radicals in the presence of superoxide and hydrogen peroxide [25]. Thus, the redox state and concentration of iron ions in the cellular milieu plays a crucial role in amplification of damage [26] as they interact with membranes to generate alkoxyl and peroxyl radicals, thereby inflicting further damage to the cellular system [27].

Superoxide is biologically important since it can be decomposed to form stronger oxidative species such as singlet oxygen and hydroxyl radicals, which are very harmful to the cellular components in a biological system [28]. Superoxide radical is generated from $\mathrm{O}_{2}$ by

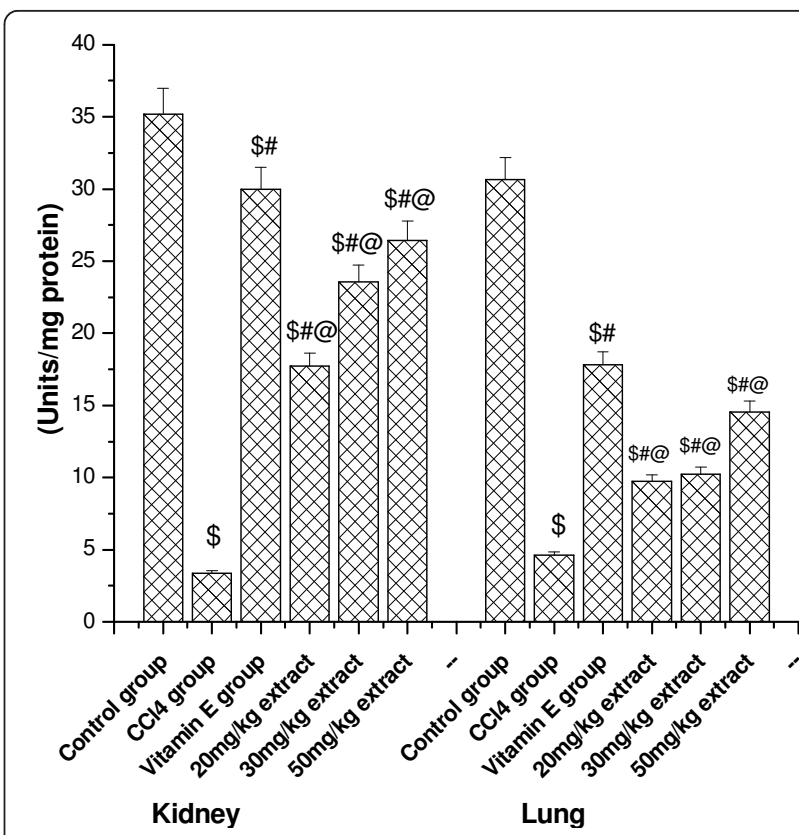

Figure 7 Represents the effect of aqueous extract of Podophyllum hexandrum on the superoxide dismutase activity in kidney and lung tissue organs. $\$ ; p<0.001$, as compared with normal control group, \#; $p<0.001$ as compared with $\mathrm{CCl}_{4}$ group, @; $p<0.001$ as compared with V.E. The data were presented as means \pm SD for six animals in each observation and evaluated by one-way ANOVA followed by Bonferroni $t$ - test to detect inter group differences. Differences were considered to be statistically significant if $p<0.05$.

multiple pathways $[29,30]$. Using NBT assay system to generate superoxide radical, dose dependent inhibition was observed in the increasing concentration of Podophyllum hexandrum rhizome aqueous extract indicating its potential to possess scavenging properties.

Hydrogen peroxide itself is not very reactive, but it can give highly reactive species ${ }^{\circ} \mathrm{OH}$ radical through Fenton reaction [31]. Earlier reports suggest that $\mathrm{H}_{2} \mathrm{O}_{2}$ could induce DNA break in the intact cell and purified DNA [32]. The $\mathrm{H}_{2} \mathrm{O}_{2}$-scavenging activity of Podophyllum hexandrum aqueous extract and the standard BHT increased in a dose dependent manner. With comparable results observed at highest concentration. Similar results were reported by Duh [33] for Chrysanthemum morifolium with high relationship between phenolic content and scavenging activity of the aqueous extracts on hydrogen peroxide. As previously reported by Chaudhary et al., that Podophyllum hexandrum possess strong antioxidant activity against superoxide and hydroxyl radical under in vitro conditions [34]. Chawla et al., have also established the antioxidant potential of different extracts of Podophyllum hexandrum [35].

The level of kidney and lung MDA in $\mathrm{CCl}_{4}$ treated group was significantly higher than the control group. The increase in MDA level in both the tissues suggests 


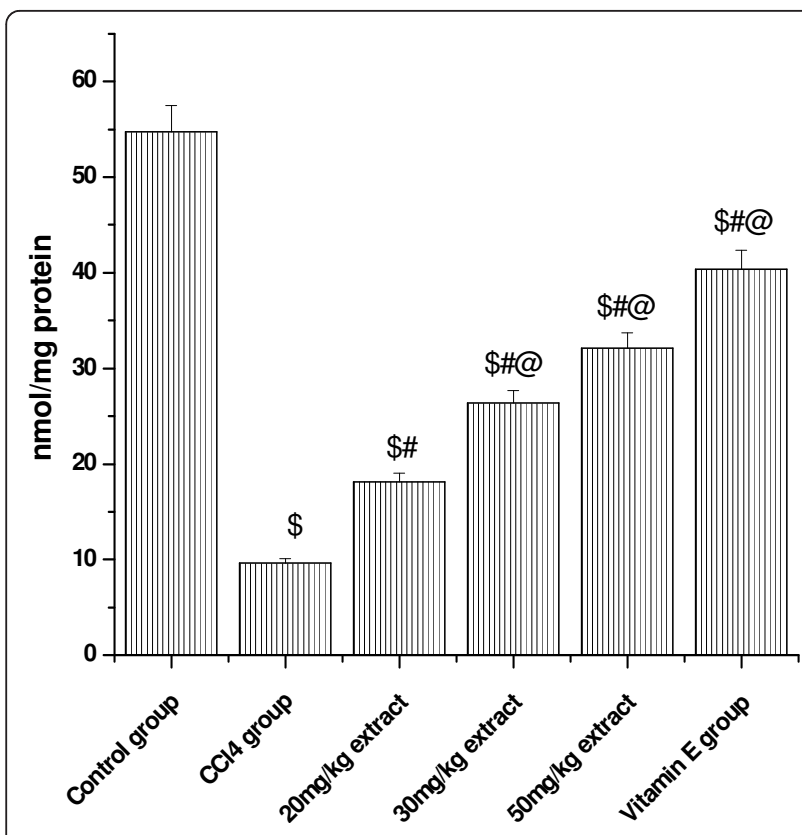

Figure 8 Represents the effect of aqueous extract on GSH levels in $\mathrm{CCl} 4$ induced Kidney damages in rats. \$; $p<0.001$, as compared with normal control group, \#; $p<0.001$ as compared with $\mathrm{CCl}_{4}$ group, @; $p<0.001$ as compared with V.E. The data were presented as means \pm SD for six animals in each observation and evaluated by one-way ANOVA followed by Bonferroni $t$ - test to detect inter group differences. Differences were considered to be statistically significant if $p<0.05$

enhanced peroxidation leading to tissue damage and failure of the antioxidant mechanisms to prevent the production of excessive free radicals. Our previous results have shown that ethanolic extract of Podophyllum hexandrum possess strong hepatoprotective activity against $\mathrm{CCl}_{4}$ induced damage in albino rats [36]. Similar results were previously reported in kidney by Ogeturk [37] and liver tissues by Yang [38] and Melin [39], which stated that $\mathrm{CCl}_{4}$ metabolized by cytochrome $\mathrm{p}$ 450 generates a highly reactive free radical, and initiates lipid peroxidation of the cell membrane of the endoplasmic reticulum and causes a chain reaction. These reactive oxygen species can cause oxidative damage in DNA, proteins and lipids. However pretreatment of Podophyllum hexandrum extract in this study significantly prevent $\mathrm{CCl}_{4}$-induced lipid peroxidation in kidney and lung tissue. Our results are in conformation to the already published report by Padma and Setty [40] that administration of aqueous extract of Phyllanthus fraternus significantly decreased the carbon tetrachloride induced lipid peroxidation in different organs of rats under in vivo conditions.

GSH as we know is involved in several defense processes against oxidative damage protects cells against free radicals, peroxides and other toxic compounds [41].

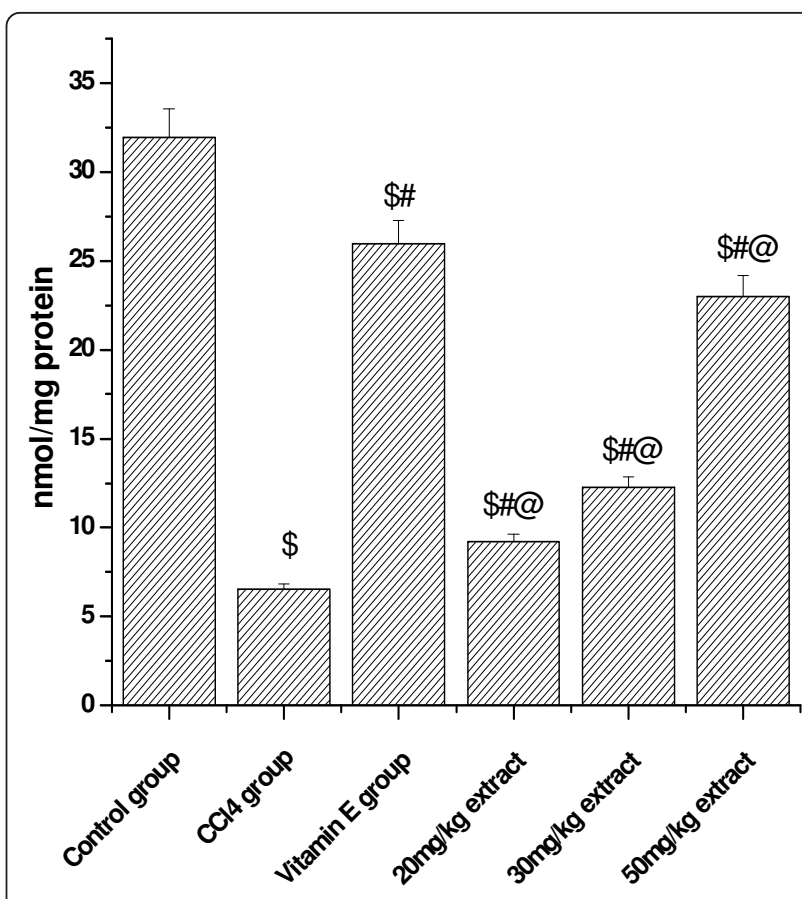

Figure 9 Represents the effect of aqueous extract of Podophyllum hexandrum on GSH levels in $\mathrm{CCl}_{4}$ induced lung damages in rats. $\$ ; p<0.001$, as compared with normal control group, \#; $p<0.001$ as compared with CCl4 group, @; $p<0.001$ as compared with V.E. The data were presented as means \pm SD for six animals in each observation and evaluated by one-way ANOVA followed by Bonferroni $t$ - test to detect inter group differences. Differences were considered to be statistically significant if $p<0.05$.

Indeed, glutathione depletion increases the sensitivity of cells to various aggressions and also has several metabolic effects. It is widely known that a deficiency of GSH within living organisms can lead to tissue disorder and injury [42]. In our study, the kidney and lung GSH level in $\mathrm{CCl}_{4}$ treated group was significantly decreased compared with control group. Likewise we [36] and others, Ohta [43], reported a significant decrease in the GSH content in different organs of rats, when injected with $\mathrm{CCl}_{4}$. Pretreatment however, with Podophyllum hexandrum aqueous extract increased GSH level as compared with $\mathrm{CCl}_{4}$ groups and thus affording protection. The antioxidant effects are likely to be mediated by the restoration of $\mathrm{CCl}_{4}$ induced decreased SOD, GR, GPx and GST activities in various tissues of rats. Treatment of rats with Podophyllum hexandrum aqueous extract significantly increased rat lung and kidney SOD, GR, GST and GPx activities. Tirkey [44] have recently conducted experiments to determine the effect of $\mathrm{CCl}_{4}$ on the renal damages in rats and obtained similar results. All these enzymes are major free radical scavenging enzymes that have shown to be reduced in a number of pathophysiological processes and diseases such as diabetes [45]. Thus, activation of these enzymes by the administration of 


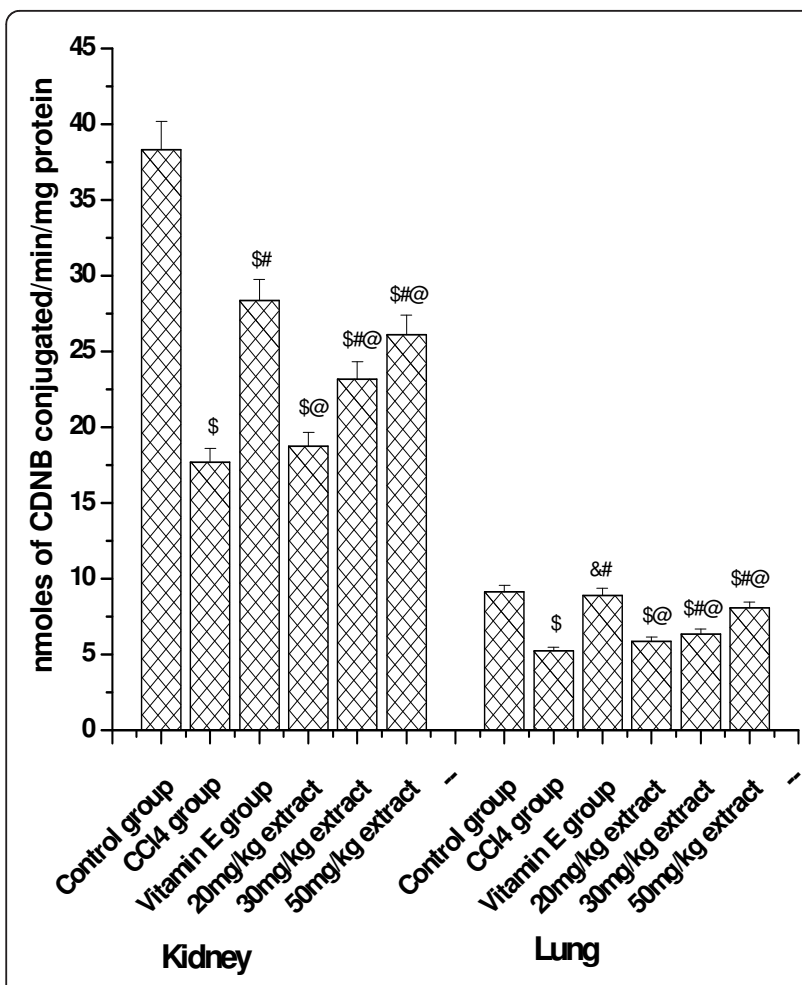

Figure 10 Effect of aqueous extract on glutathione-Stransferase activity. Left panel shows the effect of extract on kidney tissue and right panel shows the effect on lung tissue against CCl4 induced damages. \$; $p<0.001$, as compared with normal control group, \#; $p<0.001$ as compared with CCl4 group, $@ ; p<0.001$ as compared with V.E; \&; non significant as compared with normal control. The data were presented as means \pm SD for six animals in each observation and evaluated by one-way ANOVA followed by Bonferroni $t$ - test to detect inter group differences. Differences were considered to be statistically significant if $p<0.05$.

Podophyllum hexandrum aqueous extract clearly shows that Podophyllum through its free radical scavenging activity could exert a beneficial action against pathophysiological alterations caused by the presence of superoxide, hydrogen peroxide and hydroxyl radicals.

\section{Conclusion}

Combining all, we could conclude that the aqueous extract of Podophyllum hexandrum exhibits good antioxidant activity in both in vitro and in vivo experiments. In vitro antioxidant tests proved that the plant possesses components with strong superoxide and hydrogen peroxide radical scavenging activity. Study also suggests that the extract also possess potential to protect the kidney and lung tissue against oxidative damages and could be used as an effective protector against $\mathrm{CCl}_{4}$ induced kidney and lung damages. Further works are needed to fully characterize the active principles present in the plant responsible for these functions and elucidate its possible mode of action.

\section{Acknowledgements}

This study was in part funded by National Medicinal Plants Board, Department of AYUSH, Ministry of Health and Family Welfare, GOI, to Dr. M. A Zargar wide grant No. Z18017-187/PR/GO/JK/04/2005-06/ NMPB, the assistance is greatly acknowledged. The authors are thankful to Dr. Irshad Ahmad Nawchoo and Akhter Hussain Malik for identifying and authenticating the plant material used during the course of this study.

\section{Author details}

'Department of Biochemistry, University of Kashmir, Srinagar, 190006, India. ${ }^{2}$ Department of Pharmaceutical Sciences, University of Kashmir, Srinagar, 190006, India. ${ }^{3}$ Department of Biotechnology, University of Kashmir, Srinagar, 190006, India. ${ }^{4}$ Indian Institute of Integrative Medicine (Council of Scientific \& Industrial Research), Jammu, India.

\section{Authors' contributions}

SAG: Designed the study, conducted the experiments, analyzed the data and drafted the manuscript. $\mathrm{EH}$ and $\mathrm{AH}$ : made substantial contributions to the design of the study, the collection of the data as well as the interpretation and analysis of the data. They also drafted the manuscript and gave final approval for its submission to the Journal for consideration of publication. AM: made substantial contributions to the design of the study, the collection of the data as well as the interpretation and analysis of the data. He also drafted the manuscript and gave final approval for its submission to the Journal for consideration of publication. MAZ: the investigation-in-charge for the study, made substantial contributions to the design of the study, as well as the interpretation and analysis of the data. He also drafted the manuscript and gave final approval for its submission to the Journal for consideration of publication. YQ, ZM and BAZ: Made substantial contributions in the design of study and also helped in the compilation of the manuscript. All authors read and approved the final manuscript.

\section{Competing interests}

The authors declare that they have no competing interests.

Received: 8 November 2010 Accepted: 28 February 2011 Published: 28 February 2011

\section{References}

1. Rice-Evans CA, Miller NJ: Antioxidant activities of flavonoids as bioactive components of food. Biochemical Soc Trans 1996, 24:790-795.

2. Satue-Gracia MT, Heinonen IM, Frankel EN: Anthocyanins as antioxidants on human low-density lipoprotein and lecithin-liposome systems. J Agric Food Chem 1997, 45:3362-3367.

3. Halliwell B: The biological toxicity of free radicals and other reactive oxygen species. In Free radicals and food additives. Edited by: Aruoma Ol, Halliwell B. Taylor 1991:41-45.

4. Kim HJ, Odendhal S, Bruckner JV: Effect of oral dosing vehicles on the acute hepatotoxicity of carbon tetrachloride in rats. Toxicol Appl Pharmacol 1990, 102:34-49.

5. Mc Gregor D, Lang M: Carbon tetrachloride: genetic effects and other modes of action. Mutat Res 1996, 366:181-195.

6. Dashti H, Jeppsson B, Hagerstrand I, Hultberg B, Srinivas U, Abdulla M Bengmark S: Thioacetamide and carbon tetrachloride-induced liver cirrhosis. Eur Surg Res 1989, 21:83-91.

7. Behar-Cohen FF, Heydolph S, Faure V, Droy-Lefaix MT, Courtois Y, Goureau O: Peroxynitrite cytotoxicity on bovine retinal pigmented epithelial cells in culture. Biochem Biophys Res Commun 1996, 226:842-849.

8. Rajesh MG, Latha MS: Protective activity of Glycyrrhiza glabra Linn. on Carbon tetrachloride-induced peroxidative damage. Indian J Pharmacol 2004, 36:284-287.

9. Chopra RN, Nayar SL, Chopra IC: Glossary of Indian Medicinal Plants. Publication and Information Directorate, CSIR, New Delhi 1986, 44-46.

10. Beutner KR, Von Krogh G: Current status of Podophyllatoxin for treatment of genital warts. Semin Dermatol 1990, 9:148-152.

11. Arora R, Chawla R, Puri SC, Sagar R, Singh S, Kumar R: Radioprotective and antioxidant properties of low altitude Podophyllum hexandrum (LAPH). J Environ Pathol Toxicol Oncol 2005, 24:299-314. 
12. Chawla R, Arora R, Singh S, Sagar RK, Sharma RK, Kumar R: Podophyllum hexandrum offers radioprotection by modulating free radical flux: role of aryl-tetralin lignans. eCAM 2006, 3:503-511.

13. Jung CHS, Choi IW, Park MW, Cho HY: Antioxidant properties of various solvent extracts from wild ginseng leaves. LWT 2006, 39:266-274.

14. Ruch RJ, Cheng SJ, Klaunig JE: Carcinogenesis. 1989, 10:1003-1008.

15. Lowry OH, Rosenbrough NJ, Farr Al, Randall RJ: Protein estimation with the Folin phenol reagent. J Biol Chem 1951, 193:265-275.

16. Nichans WG, Samuelson D: Formation of malondialdehyde from phospholipid arachidonate during microsomal lipid peroxidation. Eur J Biochem 1968, 6:126-130.

17. Moren MA, Depierre JW, Mannervick B: Levels of glutathione, glutathione reductase and glutathione S-transferase activities in rat lung and liver. Biochem Biophys Acta 1979, 582:67-78.

18. Sharma N, Trikha P, Athar M, Raisuddin S: Inhibition of benzo[a]pyreneand cyclophosphamide-induced mutagenicity by cinnamomum cassia. Mutat Res 2001, 480-481:179-188.

19. Haque R, Bin-Hafeez B, Parvez S, Pandey S, Sayeed I, Ali M, Raisuddin S: Aqueous extract of walnut (Juglans regia L.) protects mice against cyclophosphamide induced biochemical toxicity. Hum Exp Toxicol 2003, 22:473-480.

20. Beauchamp C, Fridovich I: Superoxide dismutase: Improved assays and an assay applicable to acrylamide gel. Anal Biochem 1971, 44:276-287.

21. Ko KM, Ip SP, Poon MK, Wu SS, Che CT, Ng KH, Kong YC: Effect of a ligninenriched fructus schisandrae extract on hepatic glutathione status in rats: protection against carbon tetrachloride toxicity. Planta Med 1995, 61:134-137.

22. Halliwell B, Gutteridge JMC, Cross CE: Free radicals, antioxidants and human disease: where are we now? Journal of Laboratory and Clinical Medicine 1992, 119:598-620.

23. Ames BN, Shigenaga MK, Hagen TM: Oxidants, antioxidants and the degenerative disease of aging. proceedings of the national academy of sciences of the United States of America 1993, 90:7915-7922.

24. Prior RL: Fruits and vegetables in the prevention of cellular oxidative damage. American Journal of Clinical Nutrition 2003, 78:570s-578s.

25. Halliwell B, Gutteridge JMC: Oxygen toxicity, oxygen radicals, transition metals and disease. Biochem J 1984, 219:44.

26. Minlotti G, Aust SD: The requirement of iron (III) in the initiation of lipid peroxidation by iron (II) and hydrogen peroxide. J Biol Chem 1987, 262, 1098, 45.

27. Davies MJ, Slater TF: Studies on metal ion and lipoxygenase catalyzed breakdown of hydroperoxides using electron-spin-resonance spectroscopy. Biochem J 1987, 245:167.

28. Okhawa H, Ohishi N, Yagi K: Assay for lipid peroxides in animal tissues by thiobarbituric acid reaction. Anal Biochem 1997, 95:351-358.

29. Fridovich I: Fundamental aspects of reactive oxygen species or what is the matter with oxygen. Annals of the New York Academy of Sciences 1999, 893:13-18.

30. Gilbert DL: Fifty years of radical ideas. Annals of the New York Academy of Sciences 2000, 899:1-14.

31. Halliwell B: Superoxide dependent formation of hydroxyl free radicals in the presence of iron chelates. FEBS Lett 1989, 92:321-326.

32. Imlay JA, Chin SM: Toxic DNA damage by hydrogen peroxide through the Fenton reaction invivo and invitro. Science 1988, 240:640-642.

33. Duh PD, Tu YY, Yen GC: Antioxidant activity of water extracts of Harng Jyur (Chrisanthemun morifolium Ramat). Lebensm Wiss Technol 1999, 32:269-277.

34. Chaudhary P, Shukla SK, Sharma RK: REC-2006-A Fractionated Extract of Podophyllum hexandrum Protects Cellular DNA from Radiation-induced Damage by Reducing the Initial Damage and Enhancing Its Repair in vivo. eCAM 2009, 212:1-10.

35. Chawla R, Arora R, Kumar R, Sharma A, Prasad J, Singh S, Sagar R, Chaudhary P, Shukla S, Kaur G, Sharma RK, Puri SC, Dhar KL, Handa G, Gupta VK, Qazi GN: Antioxidant activity of fractionated extracts of rhizomes of high-altitude Podophyllum hexandrum: Role in radiation protection. Mol Cell Bio 2005, 273:193-208.

36. Ganie SA, Zargar MA, Masood A, Haq E: In vitro and in vivo evaluation of free radical scavenging potential of ethanolic extract of Podophyllum hexandrum. Afr J Biochem res 2010, 4(7):191-195.
37. Ogeturk M, Kus I, Colakoglu N, Zararsiz I, Ilhan N, Sarsilmaz M: Caffeic acid phenethyl ester protects kidneys against carbon tetrachloride toxicity in rats. J Ethnopharmacol 2005, 97:273-280.

38. Yang YS, Ahn TH, Lee JC, Moon CJ, Kim SH, Jun W, Park SC, Kim HC, Kim JC: Protective effects of Pycnogenol (R) on carbon tetrachlorideinduced hepatotoxicity in Sprague-Dawley rats. Food Chem Toxicol 2008, 46:380-387.

39. Melin AM, Perromat A, Deleris G: Pharmacologic application of Fourier transform IR spectroscopy: in vivo toxicity of carbon tetrachloride on rat liver. Biopolymers 2000, 57:160-168.

40. Padma P, Setty $\mathrm{OH}$ : Protective effect of Phyllanthus fraternus against thioacetamide induced mitochondrial dysfunction. Journal of Clinical Biochemistry and Nutrition 1999, 22:113-123.

41. Sies H: Glutathione and its role in cellular functions. Free Radic Biol Med 1999, 27:916-921.

42. Limon-Pacheco JH, Hernandez NA, Fanjul-Moles ML, Gonsebatt ME: Glutathione depletion activates mitogen activated protein kinase (MAPK) pathways that display organ-specific responses and brain protection in mice. Free Radic Biol Med 2007, 43:1335-1347.

43. Ohta $Y$, Kongo M, Sasaki E: Therapeutic effect of melatonin on carbon tetrachloride-induced acute liver injury in rats. J Pineal Res 2000, 28:119-26.

44. Tirkey P, Pilkwal S, Kuhad A, Chopra K: Hesperidin, a citrus bioflavonoid, decrease the oxidative stress produced by $\mathrm{CCl} 4$ in rat liver and kidney. BMC Pharmacol 2005, 5:2.

45. Cohen G, Heikkila RE: The generation of hydrogen peroxide, superoxide radical, and hydroxyl radical by 6-hydroxydopamine, dialuric acid, and related cytotoxic agents. J Biol Chem 1974, 249:2447-2452.

\section{Pre-publication history}

The pre-publication history for this paper can be accessed here:

http://www.biomedcentral.com/1472-6882/11/17/prepub

doi:10.1186/1472-6882-11-17

Cite this article as: Ganie et al:: Carbon tetrachloride induced kidney and lung tissue damages and antioxidant activities of the aqueous rhizome extract of Podophyllum hexandrum. BMC Complementary and Alternative Medicine 2011 11:17.

\section{Submit your next manuscript to BioMed Central and take full advantage of:}

- Convenient online submission

- Thorough peer review

- No space constraints or color figure charges

- Immediate publication on acceptance

- Inclusion in PubMed, CAS, Scopus and Google Scholar

- Research which is freely available for redistribution

Submit your manuscript at www.biomedcentral.com/submit
C Biomed Central 